\title{
Trigger point injection therapy in the management of myofascial temporomandibular pain
}

\section{Temporomandibular miyofasyal ăgrnlarda tetik nokta enjeksiyonu tedavisi}

\author{
Fatih ÖZKAN, ${ }^{1}$ Nilüfer ÇAKIR ÖZKAN, ${ }^{2}$ Ünal ERKORKMAZ ${ }^{3}$
}

Summary

Objectives: Myofascial pain is the most common temporomandibular disorder. The objective of this study was to compare the effectiveness of combined treatment modalities in the management of myofascial temporomandibular pain.

Methods: Fifty patients (44 female, 6 male) clinically and radiologically diagnosed with myofascial temporomandibular disorder (TMD) were selected for the study and randomly assigned to two groups of 25 patients. Group 1 patients were treated with stabilization splint (SS) and Group 2 patients were treated with trigger point injection combined with SS therapy.

Results: Positive improvement in overall signs and symptoms with statistically significant differences was observed in both groups. Group 2 showed significant reduction in visual analogue scale (VAS) scores, and statistical analysis revealed a significant difference between the VAS scores of Group 1 and Group 2 at the 4th and 12th weeks of treatment follow-up $(p<0.001)$.

Conclusion: Our results indicate that trigger point injection therapy combined with splint therapy is effective in the management of myofascial TMD pain. Further research, especially randomized controlled trials, should be carried out to ascertain its effectiveness over other treatment modalities.

Key words: Myofascial temporomandibular disorder; treatment modalities; trigger point injection.

\section{Özet}

Amaç: Miyofasyal ăgrılar en sık görülen temporomandibular bozukluklardır. Bu çalışmada, miyofasyal temporomandibular ağrının tedavisinde kombine tedavi yöntemlerinin etkinliği karşılaştırıldı.

Gereç ve Yöntem: Klinik ve radyolojik olarak miyofasyal temporomandibular bozukluk tanısı almış 50 basta (44 kadın, 6 erkek) çalışmaya alındı ve randomize olarak her grupta 25 hasta olacak şekilde iki gruba ayrıldı. Grup 1 stabilizasyon splinti (SS) ile Grup 2 ise SS tedavisi ile kombine olarak tetik nokta enjeksiyonlarıyla tedavi edildi.

Bulgular: Genel bulgu ve belirtilerin düzelmesinde her iki grup arasinda istatistik olarak önemli farklar bulundu. VAS skorlarmda Grup 2'de önemli azalma görüldü ve istatistitiksel analiz sonucu tedavinin 4. ve 12. haftasında yapılan değerlendirmelerde Grup 1 ve Grup 2 arasında VAS skorları açısında önemli farklar bulundu ( $p<0.001)$.

Sonuç: Bizim sonuçlarımız miyofasyal temporomandibular bozukluklarda splint tedavisiyle kombine edilen tetik nokta enjeksiyon tedavisinin etkili olduğunu gösterdi. Özellikle bu yöntemin diğer tedavi yöntemleri üzerine etkinliğini belirlemek için daha fazla sayıda randomize kontrollü çalı̧ma yapılmalıdır.

Anahtar sözcükler: Miyofasyal temporomandibular bozukluk; tetik nokta enjeksiyonu, tedavi yöntemleri.

Departments of ${ }^{1}$ Anesthesiology and Reanimation, ${ }^{2}$ Oral and Maxillofacial Surgery,

${ }^{3}$ Biostatistics, Gaziosmanpaşa University Faculty of Medicine, Tokat, Turkey

Gaziosmanpaşa Üniversitesi Tıp Fakültesi, 'Anesteziyoloji ve Reanimasyon Anabilim Dalı, 'ª̆ız-Diş Çene Hastalıkları ve Cerrahisi Kliniği, ${ }^{3}$ Biyoistatistik Anabilim Dalı, Tokat

Submitted - December 17, 2010 (Başvuru tarihi - 17 Aralık 2010) Accepted after revision - March 23, 2011 (Düzeltme sonrası kabul tarihi - 23 Mart 2011)

Correspondence (İletişim): Fatih Özkan, M.D. Ondokuz Mayıs Üniversitesi Tıp Fakültesi, Anesteziyoloji Anabilim Dalı, Samsun, Turkey.

Tel: +90 - 362 - 3121919 e-mail (e-posta):dr.fat.oz@hotmail.com 


\section{Introduction}

Temporomandibular disorder (TMD) is the general term used to describe the manifestation of pain and/or dysfunction of the temporomandibular joint (TMJ) and associated structures. ${ }^{[1]}$

Myofascial pain is the most common temporomandibular disorder. There are many synonyms for this condition including TMJ dysfunction syndrome, craniomandibular dysfunction, myofascial pain dysfunction syndrome (MPDS). ${ }^{[2]}$

In the head and neck region, myofascial pain syndrome with trigger points can manifest as tension headache, tinnitus, TMJ pain and torticollis. A trigger point $(\mathrm{Tr} P)$ is a focus of hyperirritability in a tissue that, when compressed is locally tender and hypersensitive and gives rise referred pain a tenderness. Although the pain occurs most often in the region over the TrP, pain can be referred to areas distant from the trigger points (TrPs). TrPs may be relieved through noninvasive measures, such as spray and stretch, transcutaneous electrical stimulation, physical therapy, and massage. Invasive treatments for myofascial trigger points include injections with local anesthetics, corticosteroids or botulism toxin, or dry needling. Precise injections into the trigger points are vital in helping deactivate them. ${ }^{[3]}$

The primary goal in treatment of myofascial temporomandibular pain is to alleviate pain and/or mandibular dysfunction. Many different therapiessome conservative and reversible, others irreversible, including surgery have been advocated for patients with MPDS ${ }^{[4]}$ A number of successfull treatment outcomes have been reported, including occlusal splints, physiotherapy, muscle relaxing appliances, stres-reduction techniques and pharmacotherapy. Various types of occlusal splints have been used in the management of MPDS. The stabilization splint (SS), one such type of occlusal splint, is a hard acrylic splint that provides a temporary and removable ideal occlusion. It reduces abnormal muscle activity and produces neuromuscular balance. ${ }^{[5,6]} \mathrm{TrP}$ injection has been shown to be other effective treatment option in management of the MPDS. While relatively few controlled studies on $\mathrm{TrP}$ injection have been conducted, this therapy has become widely accepted. These therapies may be used as sole treatment, but use of combined approach has been found more effective by some authors in the literature. ${ }^{[4,7]}$

To our knowledge, in the literature any other investigation which compared SS therapy and $\operatorname{TrP}$ injection therapy is not reported. The objective of the present study was to evaluate the effectiveness of combined treatment modalities in the management of myofascial temporomandibular pain. Therefore, we compared conventional SS therapy with TrP injection combined with SS therapy.

\section{Materials and Methods}

After the study was approved by the local ethic committee, the subjects were informed about the study procedure and written informed consent was obtained. The subjects were selected from TMD patients referred to the Clinic of Oral and Maxillofacial Surgery over a period of Jun 2006 to April 2008. Patients suspected to have a dominant muscular disorder and myofascial pain of all degrees of severity were included. The clinical diagnosis was myofascial pain according to the Research Diagnostic Criteria for TMD. ${ }^{[8]}$ Inclusion criteria were pain of muscular origin with or without limited opening, duration of pain at least 3 months including a complaint of pain associated with localized areas of tenderness to palpation in masticatory muscles, combined with self-assessed myofascial pain of at least $40 \mathrm{~mm}$ on a $100-\mathrm{mm}$ visual analogue scale (VAS).

To exclude odontogenic reasons for the orofacial pain, a panoramic radiographic evaluation was performed for all patients. Patients with evidence of bone pathology (rheumatoid arthritis, osteoarthrosis, condylar resorption) and who had TMJ pain, previous treatment for TMD, use of complete dentures were excluded. Another cases such as trigeminal neuralgia, atypical facial pain were also excluded from this study.

One clinician performed the screening, historytaking, clinical examination including recording the maximal incisal opening (MIO), pain during mandibular movements, noting joint noises and locking, lateral and posterior tenderness of the TMJ. TMJ, masticatory muscles were palpated for TrPs. 
Tenderness of the muscles of mastication were assessed by means of digital palpation and functional manipulation. The questionnaire used before and after the treatment included questions about pain frequency, intensity and duration. Intensity rates of pain were recorded on a VAS, 100 -mm long continuum. ${ }^{[9]}$ The tenderness in the muscle and the number of the TrPs was recorded as being present or absent. The clinical examination, performed before and after treatment by the same examiner. Another specialist who was not involved in the examination at baseline and at follow-up delivered and adjusted the appliance and $\operatorname{TrP}$ injections were performed by pain specialist.

Groups: Fifty patients clinically and radiologically diagnosed with temporomandibular myofascial pain were selected for the study and randomly assigned to two equal Group 1 ( 21 female, 4 male) and Group 2 (23 female, 2 male) consisting of 25 patients each. The mean ages of the patients were $(30.36 \pm 8.94$ years in group 1$)$ and $(30.4 \pm 9.22$ years in group 2) in respectively.

Group 1: These patients were treated with SS. An upper impression was taken at first visit and SS was made with hard acrylic (Figure 1). At the second visit SS was adjusted. Patients were instructed to wear the splint at night for a period of three months. Patients recalled for splint control one week later.

Group 2: These patients were treated with TrPs injection in combination with SS therapy. TrP injections were applied into the affected masseter (22

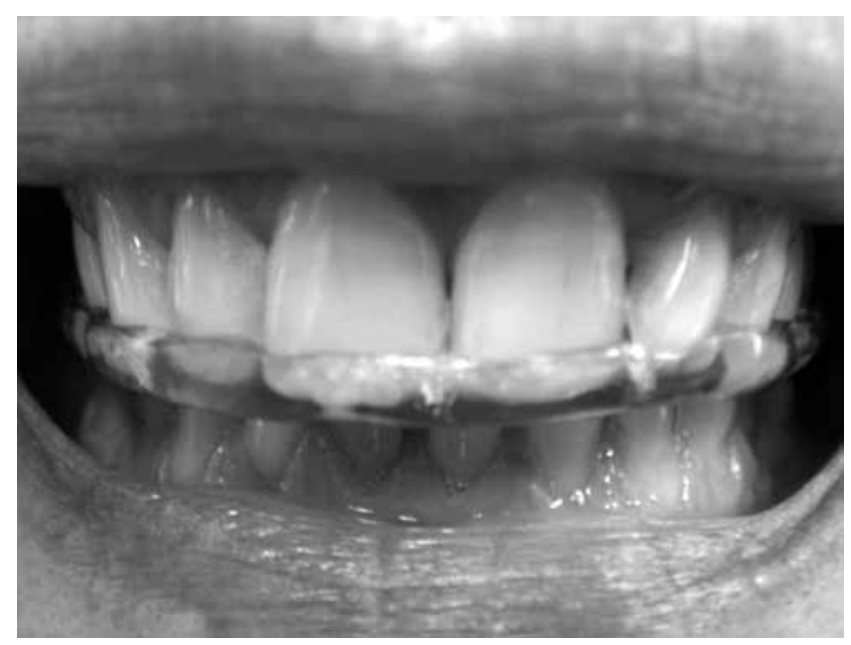

Figure 1. Stabilization splint constructed from hard acrylic. injections), temporalis (13 injections) and lateral pterygoid muscles (20 injections).

Technique: The area of maximum tenderness was identified within the affected muscle. After antiseptic preparation of the skin, the muscle was stabilized between the thumb and forefinger. A small gauge needle was introduced into the $\operatorname{Tr} \mathrm{P}^{[10]}$ The patient was asked about the location and intensity of the pain evoked by needle placement. Local anesthetic solution of $0.5 \mathrm{ml}$ lidocaine $+0.5 \mathrm{ml}$ saline was then injected into the TrP. Injections were repeated three times with two days interval. Pressure was then applied to the injected area for local hemostazis. At first and second visit, local anesthetic + saline mixture, at third visit $0.1 \mathrm{ml}$ triamcinolone acetanide injection was applied.

The patients were recalled for examination 2 week, 4 week and 12 week later after SS and TrP injections were completed. During each visit the patients were asked for their subjective assessment of pain according to VAS scale.

\section{Statistical Analysis}

The Chi-square Test was used for comparison of the categorical variables between the two groups. Marginal Homogenity Test was used to determine the difference of categorical variables between before and after the treatment. Categorical variables were presented as number and percentage. Two Independent Samples t-test was used for comparison of the continuous variables between the two groups. Two Dependent Samples t-test was used to determine the significance of differences of continuous variables between before and after the treatment within the groups.

The VAS scores between the groups were compared with the Independent Samples t-test. One-way ANOVA was used for the comparison of VAS scores within the groups. Two-way ANOVA was used for the comparison of the variation of VAS scores between the groups. P value $<0.05$ was considered statistically significant. Analyses were performed using commercial software (PASW v.18, SPSS Inc, Chicago, IL). 


\section{Results}

Table 1 shows the comparison of different variables measured between the two groups at the time of diagnosis and at 12 week follow-up. Positive treatment outcomes were found in both groups at the follow-up for signs and symptoms. In both groups, significant reduction was found in the frequency of pain and intensity of pain $(\mathrm{p}<0.001)$. The number of TrPs of the masticatory muscles was decreased with statistical significant difference (Group 1 $\mathrm{p}=0.004$, Group $2 \mathrm{p}<0.001)$. Statistically significant reduction were found in the number of patients myofascial pain at rest (Group $1 \mathrm{p}=0.001$, Group $2 \mathrm{p}<0.001)$ and during mandibular movements $(\mathrm{p}=0002$ in group 1 and $\mathrm{p}<0.001$ in Group 2). In addition, there were statistically significant differences between the groups after the treatment for signs and symptoms, pain during mandibular movements $(\mathrm{p}=0.005)$, number of $\operatorname{Tr} \mathrm{P}(\mathrm{p}=0.001)$ and intensity of pain $(\mathrm{p}=0.004)$, in respectively. Improvement of overall subjective symptoms was reported by all patients in both groups, with a statistically significant difference between the groups ( $\mathrm{p}=0.033)$, (Table 1).

MIO was presented as mean \pm standard deviation in both groups at the time of diagnosis and followup period. MIO showed a little more increase in Group $2(36.6 \pm 1.7,40.1 \pm 1.6)$ compared to Group $1(37.5 \pm 2.38,39.9 \pm 1.7)$ during the three months follow-up. However, this increase was found statistically significant (in both groups $\mathrm{p}<0.001$ ), but, there was not statistically significant difference between the two groups $(p=0.7)$. VAS scores for pain intensity showed significant reduction in both groups $(\mathrm{p}<0.001)$. Statistically significant difference was found in the variation of VAS scores between

Table 1. The comparison of different variables between the two groups

\begin{tabular}{|c|c|c|c|c|c|}
\hline \multirow[t]{2}{*}{ Signs and symptoms } & \multicolumn{2}{|c|}{ Before } & \multicolumn{2}{|c|}{ After } & \multirow[t]{2}{*}{$\mathbf{p}$} \\
\hline & $\begin{array}{c}\text { Group } 1 \\
n=25(\%)\end{array}$ & $\begin{array}{c}\text { Group } 2 \\
n=25(\%)\end{array}$ & $\begin{array}{c}\text { Group } 1 \\
n=25(\%)\end{array}$ & $\begin{array}{c}\text { Group } 2 \\
n=25(\%)\end{array}$ & \\
\hline \multicolumn{6}{|l|}{ Frequency of myofascial pain } \\
\hline Never & 0 & 0 & $8(32)$ & $14(56)$ & 0.093 \\
\hline Rarely & 0 & 0 & $11(44)$ & $10(40)$ & \\
\hline Once a month & 0 & 0 & $4(16)$ & $1(4)$ & \\
\hline Once a week & $1(4)$ & 0 & $2(8)$ & 0 & \\
\hline Twice a week & $5(20)$ & $4(16)$ & 0 & 0 & \\
\hline Daily or constantly & $19(76)$ & $21(84)$ & 0 & 0 & \\
\hline Pain at rest & $17(68)$ & $18(72)$ & $5(20)$ & $1(4)$ & 0.087 \\
\hline Pain during mandibular movements & $23(92)$ & $24(96)$ & $12(48)$ & $2(8)$ & 0.005 \\
\hline \multicolumn{6}{|l|}{ Masticatory muscles } \\
\hline 0 & 0 & 0 & $3(12)$ & $9(36)$ & 0.001 \\
\hline $1-3$ trigger point & $5(20)$ & $4(16)$ & $9(36)$ & $14(56)$ & \\
\hline$\geq 4$ trigger point & $20(80)$ & $21(84)$ & $13(52)$ & $2(8)$ & \\
\hline \multicolumn{6}{|l|}{ Intensity of myofascial pain } \\
\hline No pain & 0 & 0 & $3(12)$ & $12(48)$ & 0.004 \\
\hline Slight & $1(4)$ & 0 & $17(68)$ & $13(52)$ & \\
\hline Moderate to severe & $16(16)$ & $14(56)$ & $4(16)$ & 0 & \\
\hline Severe or very severe & $8(32)$ & $11(44)$ & $1(4)$ & 0 & \\
\hline \multicolumn{6}{|l|}{ Improvement of subjective symptoms } \\
\hline Beter & 0 & 0 & $20(87)$ & $13(54.2)$ & 0.033 \\
\hline Much better & 0 & 0 & $3(13)$ & $11(45.8)$ & \\
\hline Reciprocal clicking & $13(52)$ & $14(56)$ & $12(10)$ & $11(10)$ & 1.00 \\
\hline
\end{tabular}


Table 2. VAS scores of Group 1 and Group 2

\begin{tabular}{|c|c|c|c|c|c|}
\hline & & $\begin{array}{c}\text { Group } 1(n=25) \\
\text { Mean } \pm S D\end{array}$ & $\begin{array}{c}\text { Group } 2(n=25) \\
\text { Mean } \pm S D\end{array}$ & $\mathbf{T}$ & $\mathbf{P}$ \\
\hline \multirow[t]{6}{*}{ Pain intensity VAS (mm) } & Before & $7.20 \pm 1.50$ & $7.48 \pm 1.71$ & 0.62 & 0.541 \\
\hline & 2 week follow-up & $5.83 \pm 1.27$ & $4.92 \pm 1.44$ & 2.35 & 0.023 \\
\hline & 4 week follow-up & $4.64 \pm 1.25$ & $3.00 \pm 1.12$ & 4.88 & $<0.001$ \\
\hline & 12week follow-up & $3.16 \pm 1.52$ & $1.40 \pm 1.16$ & 4.61 & $<0.001$ \\
\hline & & $F=96.71, p<0.001 *$ & $\mathrm{~F}=172.31, \mathbf{p}<\mathbf{0 . 0 0 1 *}$ & & \\
\hline & \multicolumn{5}{|c|}{$\mathrm{F}=9.74, \mathrm{p}=\mathbf{0 . 0 0 3}$} \\
\hline
\end{tabular}

the groups ( $\mathrm{p}=0.003)$. Group 2 showed significant reduction in VAS scores and statistical analysis revealed significant difference between VAS scores of Group 1 and Group 2 at 4 week and 12 week follow-up period $(\mathrm{p}<0.001)$ (Table 2$)$, (Figure 2).

\section{Discussion}

TMDs are principally musculoskeletal, orthopedic and neurologic in nature. In this view various treatment modalities for these patients have been tried and tested over time. Myofascial pain is the most common temporomandibular disorder. Choosing a specific conservative treatment modality for TMJ dysfunction syndrome patients depends on clinicians expertise, patient presentation and elimination of possible etiologic factors. In our case series, patients were considered to belong to the category of myofascial TMD based on clinical diagnosis. No significant difference was observed between Group

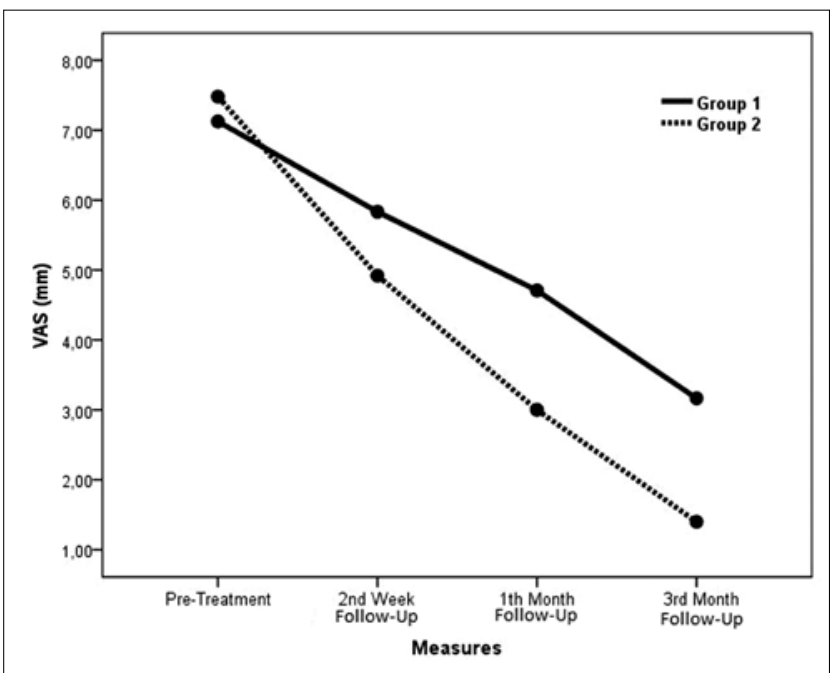

Figure 2. Mean VAS scores of Group 1 and Group 2 at the time of diagnosis and follow-up.
1 and Group 2 for the distribution of clinical signs and symptoms. There were no patients in our series who presented with clicking or joint noise alone without tenderness around the TMJ and the associated masticatory muscles.

Various treatment modalities for TMD have been tried and tested. The use of combined approach has been found by some authors to result in more rapid symptom relief, decreased treatment time and overall superior therapeutic outcome in the treatment of myofascial TMD pain. Till date, no single treatment modality has been found more successfull than any combined therapy. ${ }^{[9,11]}$ In the present study, we evaluated the efficacy of TrP injection therapy combined with occlusal splint therapy in the management of myofascial TMD pain.

Occlusal splint therapy is commonly used conservative treatment modalities and is useful in the reduction of pain and tenderness in the muscles in MPDS patients. Generally, the conclusions of randomised controlled trials themselves regarding treatment outcome have been positive. Dao and Lavigne (1998) and Turk et al. (1993) found positive treatment outcome with SS therapy in patients suffering from myofascial TMD pain. ${ }^{[12,13]}$ Ekberg et al. ${ }^{[14]}$ (2003) reported positive efficacy of stabilization appliance on the intensity of myofascial pain, pain during mandibular movements, maximal opening capacity and the number of trigger points of the masticatory muscles. However, Raphael et al. ${ }^{[15]}$ (2003) conclude that oral splints were of modest value for patients with myofascial face pain in their overall sample. Results of our study agree with various studies supporting the usefullness of occlusal splints in the management of TMJ dysfunction 
syndrome. ${ }^{[5,16-18]}$ But, our results showed that $\operatorname{Tr} \mathrm{P}$ injection combined with SS therapy was more effective in the treatment of myofascial TMD pain for signs and symptoms improvement.

Naikmasur, et al. (2008) and Suvinen and Reade (1989) have also shown $10.02 \mathrm{~mm}$ and $7.4 \mathrm{~mm}$ increase in MIO after splint therapy in MPDS patients. ${ }^{[19,20]}$ Wong and Cheng (2003) achieved normal mouth opening ( $\mathrm{MIO} \geq 40 \mathrm{~mm}$ ) in their patients by the end of treatment with combination of acupuncture+SS+point injection therapy. ${ }^{[21]}$ Similarly, we achieved normal mouth opening (mean= $40.12 \mathrm{~mm}$ ) at the end of the treatment follow-up in Group 2.

In our study, it was observed significant and progressive reduction in VAS scores and the number of tender points during three months treatment follow-up in Group 1. Raphael et al. ${ }^{[15]}$ (2003) have also found that occlusal splints had decreased the VAS scores and the number of painful muscles in during a six-week follow-up study in patients with myofascial pain. This is in agreement with our conclusions. Turk et al. ${ }^{[13]}$ (1993) found that significant short-term effect on pain, comparing an intraoral appliance with biofeedback/stress management in TMD. Naikmasur et al. ${ }^{[19]}$ (2008) imply that the oclusal splint causes a slow and steady improvement in TMJ symptoms. Dao and Lavigne (1998) and Ekberg et al. (2003) concluded that oral splints should be used as an adjunct for pain management rather than as a specific treatment modality. ${ }^{[12,14]}$ TMD tends to be a chronic recurrent pain condition therefore, patients with myofascial pain in general should be treated with more effective treatment regimen.

Our patients in Group 2 experienced a decrease in the intensity of myofascial pain and a progressive improvement in TMJ symptoms in comparison to Group 1. It was observed in significant reduction in VAS scores during three-month follow-up, especially in the third month of follow-up $(\mathrm{p}=0.00)$. This is consistent with the conclusions of Wong and Cheng $^{[21]}$ (2003) who performed point injection for residual TrPs after the acupuncture treatment. It has been established that referred pain to the TMJ and other head and neck locations is commonly result of active trigger points in the muscles of mastication, sternocleidomastoid, cervical and trapezius muscles. ${ }^{[21]}$ In our opinion, the improvement of symptoms in Group 2 may indicate that referred pain from the TMJ and associated structures decreased as a result of myofascial $\mathrm{TrP}$ injection therapy. The number of patients with $\geq 4$ tender points of the masticatory muscles significantly decreased in TrP Group. Presence of TrPs after the point injection may be resulted from unsuccessful injections or the medial pterygoid muscle can not be injected.

Both invasive and non-invasive techniques have been used in the treatment of myofascial TrP pain. Gül and Önal ${ }^{[3]}$ (2009) compared non-invasive techniques with invasive techniques in patients with myofascial pain syndrome. They reported that $\operatorname{Tr} P$ injection with lidocaine or botulinum toxin-A provided better pain control when compared to noninvasive techniques such as laser and transcutaneous electrical nerve stimulation in patients with myofascial pain syndrome. However, Baldry ${ }^{[22]}$ (2002) suggested that superficial dry needling (SDN) to be sufficient in the treatment of myofascial TrP pain and if the response to SDN is inadequate, more invasive approach should be considered. With respect to point injection it is reported that the nature of the injected substance makes no difference to the outcome. ${ }^{[23]} \operatorname{TrP}$ injection therapy is a painful application and appears to have a little effect on improvement of joint noises. But, it seems to have a more rapid pain relief and decrease treatment time in patients with myofascial TMD pain, which is the chief complaint of most patients seeking therapy.

Goals of treatment TMJ dysfunction syndrome include reducing or eliminating pain, restoring normal jaw function. Simple cases can be managed by a single clinician with self-care, exercises and SS therapy. But complex patients should be managed most effectively within a interdisciplinary clinic setting that uses a team of clinicians to address different aspects of the problem in a concerted fashion. To improve outcomes, it is important to match the level of complexity of the management program and to distinguish between joint disorders and muscle disorders in TMD patients. Therefore, a careful evaluation of TrPs is useful for a correct interpretation of the orofacial muscular pain in TMD patients and 
these patients should be managed with multidisciplinary approach..$^{[3,24-26]}$

\section{Conclusion}

The results of this study indicate that TrP injection therapy, in combination with splint therapy is more effective than splint therapy alone for management of TMD. But, the present study have certain limitations like the absence of a control group without therapy, it was impossible to determine other factors (such as psychologic, placebo, spontaneous remission) could have contributed to treatment outcome. It is also difficult to compare our results with the literature, because of the lack of the studies comparing an intraoral appliance with point injection therapy in TMD. Therefore, further research, especially randomised blinded controlled trials, should be carried out to ascertain its effectiveness over other combined treatment modalities. There is need to studies comparing different treatment modalities in myofascial TMD pain.

\section{References}

1. Laskin DM. Diagnosis and etiology myofascial pain and dysfunction. Oral Maxillofac Surg Clin North Am 1995;7:73-8.

2. Gray RJM, Davies SJ, Quayle AA. A clinical guide to temporomandibular disorders. London: BDJ Books; 1997. p. 1-43.

3. Gül K, Onal SA. Comparison of non-invasive and invasive techniques in the treatment of patients with myofascial pain syndrome. Agri 2009;21(3):104-12.

4. Al-Ani Z, Gray RJ, Davies SJ, Sloan P, Glenny AM. Stabilization splint therapy for the treatment of temporomandibular myofascial pain: a systematic review. J Dent Educ 2005;69(11):1242-50.

5. Davies SJ, Gray RJ. The pattern of splint usage in the management of two common temporomandibular disorders. Part III: Long-term follow-up in an assessment of splint therapy in the management of disc displacement with reduction and pain dysfunction syndrome. Br Dent J 1997;183(8):279-83.

6. Murphy GJ. Physical medicine modalities and trigger point injections in the management of temporomandibular disorders and assessing treatment outcome. Oral Surg Oral Med Oral Pathol Oral Radiol Endod 1997;83(1):118-22.

7. Gray RJ, Davies SJ. Occlusal splints and temporomandibular disorders: why, when, how? Dent Update 2001;28(4):194-9.

8. Dworkin SF, LeResche L. Research diagnostic criteria for temporomandibular disorders: review, criteria, examinations and specifications, critique. J Craniomandib Disord 1992;6(4):301-55.
9. Okeson JP. Management of temporomandibular disorders and occlusion. St. Louis: Mosby- Year Book; 1993. p. 345-78.

10. Travell JG, Simons DG. Myofascial pain and dysfunction. The trigger point manual. Baltimore: Williams \& Wilkins; 1983.

11. Friedman $\mathrm{MH}$, Weisberg J. Temporomandibular joint disorders: diagnosis and treatment. Chicago: Quintessence Publishing Company; 1985. p. 119-40.

12. Dao TT, Lavigne GJ. Oral splints: the crutches for temporomandibular disorders and bruxism? Crit Rev Oral Biol Med 1998;9(3):345-61.

13. Turk DC, Zaki HS, Rudy TE. Effects of intraoral appliance and biofeedback/stress management alone and in combination in treating pain and depression in patients with temporomandibular disorders. J Prosthet Dent 1993;70(2):158-64.

14. Ekberg E, Vallon D, Nilner M. The efficacy of appliance therapy in patients with temporomandibular disorders of mainly myogenous origin. A randomized, controlled, short-term trial. J Orofac Pain 2003;17(2):133-9.

15. Raphael KG, Marbach JJ, Klausner JJ, Teaford MF, Fischoff DK. Is bruxism severity a predictor of oral splint efficacy in patients with myofascial face pain? J Oral Rehabil 2003;30(1):1729.

16. Dimitroulis G, Gremillion HA, Dolwick MF, Walter JH. Temporomandibular disorders. 2. Non-surgical treatment. Aust Dent J 1995;40(6):372-6.

17. Kuttila M, Le Bell Y, Savolainen-Niemi E, Kuttila S, Alanen P. Efficiency of occlusal appliance therapy in secondary otalgia and temporomandibular disorders. Acta Odontol Scand 2002;60(4):248-54.

18. Minakuchi H, Kuboki T, Matsuka $\mathrm{Y}$, Maekawa $\mathrm{K}$, Yatani $\mathrm{H}$, Yamashita A. Randomized controlled evaluation of non-surgical treatments for temporomandibular joint anterior disk displacement without reduction. J Dent Res 2001;80(3):924-8.

19. Naikmasur V, Bhargava P, Guttal K, Burde K. Soft occlusal splint therapy in the management of myofascial pain dysfunction syndrome: a follow-up study. Indian J Dent Res 2008;19(3):196-203.

20. Suvinen T, Reade P. Prognostic features of value in the management of temporomandibular joint pain-dysfunction syndrome by occlusal splint therapy. J Prosthet Dent 1989;61(3):355-61.

21. Wong YK, Cheng J. A case series of temporomandibular disorders treated with acupuncture, occlusal splint and point injection therapy. Acupunct Med 2003;21(4):138-49.

22. Baldry P. Management of myofascial trigger point pain. Acupunct Med 2002;20(1):2-10.

23. Alvarez DJ, Rockwell PG. Trigger points: diagnosis and management. Am Fam Physician 2002;65(4):653-60.

24. Cummings TM, White AR. Needling therapies in the management of myofascial trigger point pain: a systematic review. Arch Phys Med Rehabil 2001;82(7):986-92.

25. Gerwin RD. Classification, epidemiology, and natural history of myofascial pain syndrome. Curr Pain Headache Rep 2001;5(5):412-20.

26. Madland G, Newton-John T, Feinmann C. Chronic idiopathic orofacial pain: I: What is the evidence base? $\mathrm{Br}$ Dent J 2001;191(1):22-4. 